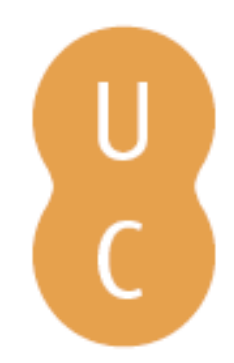

\title{
nombalina
}

\section{Osteomyelites in newbord: a case report}
Autor(es): $\quad$ Graziano, V.; Cannovo, N.; Tuccillo, A.
Publicado por: Imprensa da Universidade de Coimbra
URL
persistente:
URI:http://hdl.handle.net/10316.2/31731
DOI:
DOI:http://dx.doi.org/10.14195/978-989-26-0173-1_75

Accessed : $\quad$ 26-Apr-2023 11:57:32

A navegação consulta e descarregamento dos títulos inseridos nas Bibliotecas Digitais UC Digitalis, UC Pombalina e UC Impactum, pressupõem a aceitação plena e sem reservas dos Termos e Condições de Uso destas Bibliotecas Digitais, disponíveis em https://digitalis.uc.pt/pt-pt/termos.

Conforme exposto nos referidos Termos e Condições de Uso, o descarregamento de títulos de acesso restrito requer uma licença válida de autorização devendo o utilizador aceder ao(s) documento(s) a partir de um endereço de IP da instituição detentora da supramencionada licença.

Ao utilizador é apenas permitido o descarregamento para uso pessoal, pelo que o emprego do(s) título(s) descarregado(s) para outro fim, designadamente comercial, carece de autorização do respetivo autor ou editor da obra.

Na medida em que todas as obras da UC Digitalis se encontram protegidas pelo Código do Direito de Autor e Direitos Conexos e demais legislação aplicável, toda a cópia, parcial ou total, deste documento, nos casos em que é legalmente admitida, deverá conter ou fazer-se acompanhar por este aviso.

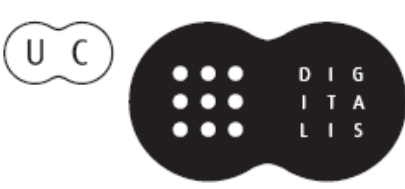




\section{Duarte Nuno Vieira Anthony Busuttil \\ Denis Cusack • Philip Beth}
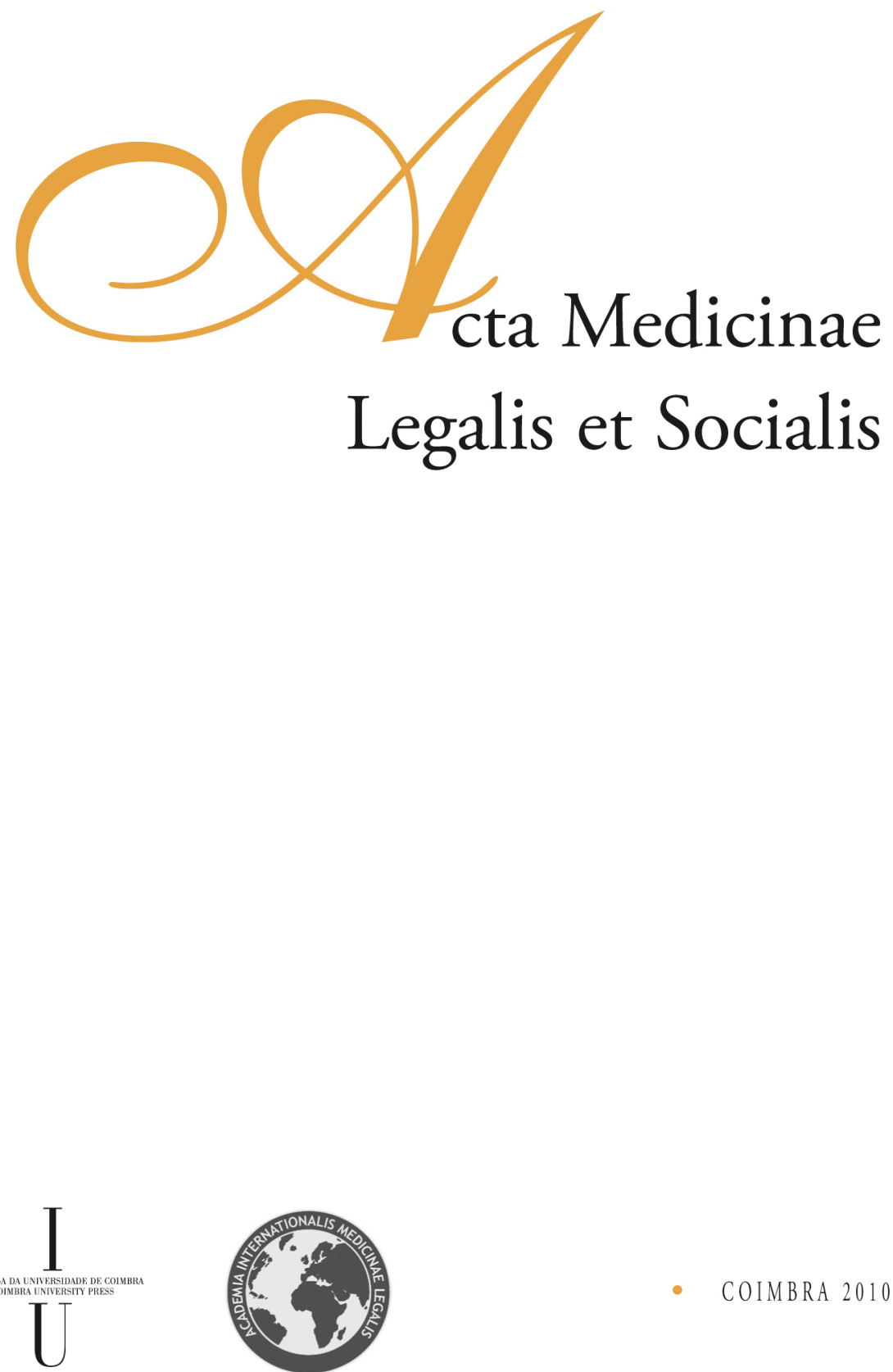
V. Graziano, N. Cannovo, A. Tuccillo

Department of Public Medicine al Public Safety, Legal Medicine Section, University of Napoli Federico II, Italy

\title{
OSTEOMYELITES IN NEWBORD: A CASE REPORT
}

\begin{abstract}
The Authors report a case of medical malpractice tied up the missed asepsis during a new born screening and the following bad management of Staphylococcus bacterial infection.
\end{abstract}

\section{Introduction}

The practice of screening the neonatal population for certain diseases (Phenylketonuria and Congenital hypothyroidism) by biochemical testing of a dried blood spot has been introduced by Italian Government in the 1992.

The public health activity aimed at the early presymptomatic identification of infants who are affected by certain genetic, metabolic or infectious conditions (1), these requirements are particularly challenging.

Heel punctures have provided an easy method of obtaining blood from neonates for biochemical screening, but this procedure has a low risk rate.

In fact, in literature the superficial infection at the puncture site is a rare occasions in small infants (2).

We report a case of osteomyelitis after heel punctures during neonatal screening program.

\section{Case report}

A $2600 \mathrm{~kg}$ infant born at 37 weeks' gestation had any right heel punctures during the first 48 hours of his life.

On the ninth day, the right heel was erythematous, swollen and tender.

On a day after admission, the infant developed fever of $38,4^{\circ} \mathrm{C}$ and he had a convulsive episode.

The patient's physical examination was remarkable for temperature of $38^{\circ} \mathrm{C}$ and rubor, calor, fuctio laesa of right food was showed.

There was no history of local trauma. There were no cardiac, thoracic and abdominal pathology in clinical diary. Inflammatory indices such as erythrocyte sedimentation rate and C-reactive protein were normal. Electrolytes were normal. 
Cultures of blood and spinal liquid grew Staphylococcus aureus that was sensitive to cefazolin, levofloxacin and oxacillin. Antibiotic therapy was started.

After two days of the admission an X-ray revealed erosion of the posterior portion of the right calcaneus compatible with osteomyelitis.

A bar was positioned on the right heel. After 45 days he came back to home. Now, the child right foot continues to grow smaller. An X-ray of the right food shows an osteolytic lesion in calcaneus.

\section{Discussion}

Osseous infection can be caused by haematogenous spread of organisms to bone (haematogenous osteomyelitis) or by direct local invasion by bacteria and the haematogenous spread of organisms follows bacteremia due to, for example, urogenital infections, enteritis, cholangitis or endocarditis; often the infective focus is not identified (3).

Osteomyelitis is defined as inflammation of bone and marrow cavity (4). Acute haematogenous osteomyelitis occurs predominantly in the paediatric age group, but the newborn disease is rare.

Usually precipitating conditions are infections of the umbilicus, ear, nose and threat often by streptococci (3).

In new born less than four months the Staphylococcus aureus, Gram- bacilli, group B Streptococcus are the most common organisms in Osteomyelitis (6).

In adult, the diagnosis of Osteomyelitis is first suspected on clinical grounds; beside, the leukocyte count may be elevated, but is often normal in chronic cases. Both erythrocyte sedimentation rate (ESR) and C-reactive protein (CRP) are elevated, and usually return to normal during the course of treatment. Confirmation of the presence of Osteomyelitis usually entails a combination of radiologic, microbiologic, and histopathologic tests.

Cross-sectional imaging modalities such as computed tomography (CT) scanning and magnetic resonance imaging (MRI) are now considered standard in the diagnosis of Osteomyelitis (7).

In newborn, Osteomyelitis is usually an acute disease which has a predilection for the proximal and distal femoral metaphyses.

In this work we report a case of Osteomyelitis by Staphylococcus aureus infection of heel after puncture.

In fact the legal medical aspect of this case is relative to correct screening procedure. The health care provider who showed the infant with systemic signs of sepsis excluded the presence of the other pathology.

The little time among heel puncture and systematic signs of sepsis and the exclusion of other pathology open to liability for health care provider who made the screening procedure. 


\section{Conclusion}

We think that the missed activation of a possible search of Staphylococcus bacterial infection, despite the characteristics clinical demonstrations in the newborn, represents a connected forgetfulness with an inexcusable defect of professional technical behavior.

The behavioral defect was stamped to inexperience and negligence because the sanitary had to set attention to the evident characteristics manifested by the newborn and to worry about to verify its motive through a simple blood investigation before the resignation from hospital.

It subsequently needs to specify that there was also an inadequacy in the management of the newborn screening from which the Staphylococcus bacterial infection was baited.

In fact, the asepsis of screening procedure in infant is very important.

Besides, the delay with which the aforesaid infection was underlined then in hospital environment was extremely prejudicial for the child; in fact Osteomyelitis was activated with following anatomic-functional repercussion to load of the left foot.

In this case the health care provider shows a neglect approach and medical malpractice negligence is serious stuff, especially when a patient is harmed unnecessarily.

\section{References}

BOHNDORF K., Infection of the appendicular skeleton Eur Radiol, 14:E53.E63, 2004.

CLAGUE A., THOMAS A., Neonatal biochemical screening for disease, Clinica Chimica Acta 315, 99-110, 2002.

GOLD R.H., HAWKINS R.A., KATZ R.D., Bacterial osteomyelitis: findings on plain radiography, CT, MR, and scintigraphy. American Journal of Roentgenology; 157(2), 365-370, 1991.

LILIEN L. D., HARRIS V. J., RAMAMURTHY R. S., PILDES R. S., Neonatal osteomyelitis of the calcaneus: complication of heel puncture. The Journal of Pediatrics, vol 88, n. 3, pp 478-480, 1976.

MAST N. H., HORWITZ D., Osteomyelitis: a review of current literature and concepts. Operative Tecniques in Orthopaedics, vol 12, n 4, pp 232-241, 2002.

SIA I. G., BERNARI E. F., Osteomyelitis, Best Practice \& Research Clinical Rheumatology, vol 20, n. 6, pp 1065-1081, 2006. 